\title{
EEN GEOLOGISCHE REIS MET UTRECHTSCHE STUDENTEN NAAR DE NEDERLANDSCHE BENEDENWINDSCHE EILANDEN
}

\author{
DOOR
}

PROF. DR. L. M. R. RUTTEN

Ongeveer vier jaar geleden kwam bij mij het plan op, om met studenten een geologische reis naar de Nederlandsche Benedenwindsche eilanden te maken, om met hen een geologische kaart van Curaçao, Aruba en Bonaire te maken; in 1930 kwam dit plan, zij het ook eenigszins anders dan oorspronkelijk gedacht was, tot uitvoering. Bij het projecteeren van deze onderzoekingsreis werd ik door zeer verschillende motieven geleid.

Het meest voor de hand liggende motief was van paedagogischen aard. Voor jonge geologen, die, als ze eenmaal afgestudeerd zijn, in den regel terreinonderzoekingen in de meest verschillende deelen der aarde gaan doen, is het een voordeel, als ze voor hun dissertatie ook al een „veld-onderwerp" nemen. Dat wil zeggen, dat ze hetzij van een bepaald gebied de geologische samenstelling en structuur onderzoeken zonder een meer bijzondere probleemstelling, of dat ze in een gebied een bepaald vraagstuk van algemeenen aard bestudeeren, voor welke studie dan het uitgekozen gebied juist geschikt moet zijn. Het wordt nu hoe langer hoe moeilijker, om in Europa nog geschikte en eenigszins maagdelijke "dissertatiegebieden" te vinden. Bovendien gaan de allermeeste afgestudeerde geologen naar landen buiten Europa en speciaal naar de Tropen. In verband hiermede is het natuurlijk voor de studenten van belang, reeds tijdens hun studie de Tropen 
te leeren kennen. Ten laatste is een niet te groot eiland een bijzonder aantrekkelijk dissertatie-onderwerp. Het is een volmaakt afgesloten gebied, dat de doctorandus geheel bewerken kan, en hij kan niet in de verleiding komen, zijn onderzoekingsgebied steeds verder uit te breiden, aangezien de omringende zee voor geologisch onderzoek ten eenenmale ongeschikt is. Mijn eerste motief was dus,dat de drie Nederlandsche Benedenwindsche eilanden ideale objecten zouden vormen voor dissertaties van drie oudere studenten, terwijl, indien er ook nog andere, jongere studenten meegingen, deze in elk geval van die reis buitengewoon veel zouden leeren.

Het tweede motief was van geologisch-wetenschappelijken aard. Het heele gebied van West-Indië is geologisch zeer belangwekkend. In de Oude Wereld ligt tusschen de vastelandsmassaas van Europa en Azië in het Noorden en Afrika, Arabië, Voor Indië en Australië in het Zuiden een gordel, die de Alpen, het Middellandsche zeegebied, Klein Azië, Perzië, Beludschistan, de Himalaya, de bergketens van westelijk Achter Indië en onzen Oost Indischen Archipel omvat, waarbij de „vaste landen” in den jongeren geologischen tijd een zeer onbewogen geschiedenis hebben gehad, terwijl de „mediterrane gordel” juist aldoor zeer bewegelijk is geweest en tengevolge daarvan een zeer belangwekkende en bewogen geschiedenis heeft gehad. Evenzoo ligt in de Nieuwe Wereld tusschen de starre massaas van Noord Amerika en Zuid Amerika een veel bewegelijker gebied, dat het noordelijkste Zuid Amerika, Centraal Amerika en de Antillen omvat.

Geologisch gesproken behooren dus de Antillen tot de bewegelijkste, dus tot de belangwekkendste gebieden op aarde, en daar komt nog bij, dat ze betrekkelijk weinig bekend zijn. Het onderzoek der Nederlandsche Benedenwindsche eilanden had dus ook in zuiver wetenschappelijk opzicht een groote charme.

Een derde motief was van min of meer nationalistischen en localen aard. De Nederlandsche gebieden in Amerika zijn betrekkelijk vroeg en voor dién tijd goed onderzocht. Prof. K. Martin uit Leiden deed, nu onge- 
veer 50 jaar geleden, geologische onderzoekingen in Suriname en in de Benedenwindsche eilanden ${ }^{\mathbf{1}}$ ); Prof. G. A. F. Molengraaff bezocht in dienzelfden tijd de Bovenwindsche eilanden ${ }^{2}$ ). Door deze onderzoekingen nam Nederland op het einde der vorige eeuw in de rij der europeesche mogendheden, die bezittingen in Amerika hadden, een eervolle plaats in. In Suriname zijn sedertdien natuurwetenschappelijke onderzoekingen, verricht tijdens expedities naar het binnenland, op ruime schaal voortgezet; ze zijn tot op zekere hoogte afgesloten door de expeditie naar het Wilhelminagebergte in 1926. Het geologigische materiaal, op alle expedities verzameld, werd in mijn instituut bewerkt door den heer R. IJzerman, die er in den zomer van dit jaar ook op gepromoveerd is; zijne dissertatie $^{3}$ ) is een zoo fraaie geologische monographie van Suriname geworden, dat men zeggen mag, dat Nederlandsch Guyana op het oogenblik in geologisch opzicht veel en veel beter bekend is dan Braziliaansch, Fransch, Engelsch en Venezolaansch Guyana. Wat wonder, dat ik, wetende, dat deze dissertatie op komst was, er veel voor voelde, dat ook de Nederlandsche Antillen van Utrecht uit nieuw onderzocht zouden worden. Voor dit hernieuwde onderzoek was inderdaad alle aanleiding. De onderzoekingen van Martin, hoe goed ook voor hun tijd, waren noodzakelijkerwijze onvolledig en vluchtig geweest. Sedertdien was een voortreffelijke topographische kaart van de eilanden verschenen, voor geologisch detailwerk een even noodzakelijke als fraaie basis vormend. Terwijl voor andere eilanden in de Antillen onze geologische kennis in mindere of meerdere mate was toegenomen, was dit voor de Nederlandsche eilanden nauwelijks het geval. Wel was door verschillende onderzoekers op Curaçao en Aruba geologisch gewerkt, maar de resultaten van hun werk wa-

1) K. Martin, Bericht über eine Reise nach Niederl. West Indien. Leiden 1888.

2) G. A. F. Molengraaff, De geol. van het eil. St. Eustatius, 1886. Id. Het geol. verband t. d. West Indische eilanden. Handel. 1ste Nat. en Geneesk. Congres 1888, p. $287-296$.

s) R. IJzerman, Outline of the geology and petrology of Surinam Utrecht 1931. 


\section{GEOLOGISCHE REIS MET UTRECHTSCHE STUDENTEN}

ren niet gepubliceerd. Ik wist toen nog niet, dat er ook voor Curaçao een nieuwe monographie, van G. J. H. Molengraaff, op komst was, die in 1929 is verschenen ${ }^{\mathbf{1}}$ ); onze definitieve plannen zijn dientengevolge iets anders geworden dan de oorspronkelijke opzet.

Ten laatste was er een argument van praktischen aard, dat me ertoe dreef, als object voor de eerste excursie, die ik met studenten naar de Tropen zou maken, de Nederlandsche Antillen te kiezen. Ik mocht er zeker op rekenen dat een dergelijk onderzoek de sympathie van het Departement van Koloniën en van den Gouverneur van Curaçao zou hebben. Het was wel onwaarschijnlijk, dat ze onze expeditie financieel zouden kunnen steunen, maar ik meende toch op hun moreelen steun te kunnen rekenen. Voor financieelen steun was ik er vrij zeker van, te kunnen aankloppen bij de twee groote lichamen, die al zoovele expedities naar de overzeesche deelen van Nederland gefinancierd hebben, n.l. de „Maatschappij ter bevordering van het Natuurkundig Onderzoek der Nederlandsche Koloniën” en het „Koninklijk Nederlandsch Aardrijkskundig Genootschap". Ik rekende erop, voor de passage naar de West reducties te krijgen van de Koninklijk Nederlandsche Stoomboot Maatschappij. In de laatste plaats was er in Curaçao een groot raffinagebedrijf van de „Koninklijke” en,omdat deze in het algemeen herhaaldelijk bewezen heeft, natuurwetenschappelijke onderzoekingen in onze Koloniën daadwerkelijk te willen steunen, en bovendien belang heeft bij een goede opleiding van geologen, mocht ik erop rekenen, dat zij ook ons bij ons werk moreel zou willen steunen.

Laat ik nu al zeggen, dat onze verwachtingen in geen enkel opzicht bedrogen zijn: integendeel, we hebben veel meer hulp en medewerking gevonden dan we redelijkerwijze mochten verwachten. De Minister van Onderwijs, Kunsten en Wetenschappen heeft een bedrag op de begrooting gebracht, om voor mij de reis mogelijk te maken; de Gouverneur van Curaçao heeft ons geholpen, waar hij

1) G. J. H. Molengraaff, Geologie en Geohydrologie van Curaçao. Delft 1929. 
kon; het Departement van Koloniën stelde alles, wat het van topographische kaarten had, ter onzer beschikking; de beide bovengenoemde wetenschappelijke Genootschappen hebben ons een subsidie verleend voor de kampeeren wetenschappelijke uitrusting der expeditie; de Kon. Nederl. Stoomb. Mij verleende ons belangrijke faciliteiten; ten laatste zijn we bij ons verblijf op Curaçao bij de „Curaçaosche Petroleum Maatschappij”, de dochtermaatschappij der „Koninklijke” kind in huis geweest.

\section{II.}

De opzet van het plan eener reis naar de Benedenwindsche eilanden was dus al oud; het duurde echter bijna drie jaar, voordat het tot uitvoering kwam. Het was in de eerste plaats noodig, deelnemers te vinden. Onder de opgroeiende studenten waren er twee, die er veel voor voelden, een dissertatie over Aruba en Bonaire te maken, de heeren J. H. Westermann en P. J. Pijpers; hunne proefschriften zullen binnen het jaar verschijnen. Er waren drie andere studenten in de geologie, die als "meeloopers" de reis wilden meedoen, de heeren L. M. J. Vermunt, H. Mac Gillavry en mijn zoon, M. G. Rutten. Tijdens de voorbereiding der reis vroeg de student in de biologie P. Wagenaar Hummelinck, of hij de reis zou mogen meemaken. Mét mijne vrouw en mij was dat een gezelschap van acht personen, dat in het najaar van 1929 besloten was, in de lente van 1930 naar Curaçao te vertrekken.

De technische voorbereidingen voor de reis waren niet omvangrijk. Het was natuurlijk noodig, de reis zoo weinig kostbaar als mogelijk te maken. Daarom wilden we zooveel mogelijk in kampen leven en onze vivres voor een belangrijk deel uit Nederland meenemen. De kampeerinrichting hebben we voor het allergrootste deel bij Carl Denig in Amsterdam gekocht; over bijna alles zijn we zeer tevreden geweest. Dat geldt voor de tenten, de kampstoelen en kamptafels en de keukeninrichting. Minder pleizier hebben we van de veldbedden gehad: deze schenen op „zeer licht gewicht” te zijn ingesteld; geen enkele veld- 


\section{GEOLOGISCHE REIS MET UTRECHTSCHE STUDENTEN}

bedbedekking heeft het tot het einde uitgehouden; herhaaldelijk is de nachtrust van een slaper gestoord, doordat plotseling het zeildoek van zijn ,stretcher" scheurde, en we zouden zeker op het laatst op den grond hebben moeten slapen,als niet de welwillende Gezaghebber van Aruba, de heer L. Wagemaker, ons met een betere qualiteit van zeildoek voor de reparatie van onze bedden ware te hulp gekomen.

We hadden natuurlijk in Nederland al gehoord, dat levensmiddelen op de eilanden zeer duur zijn en dat het noodig zou zijn, voor een belangrijk deel van ,,blikjes” te leven; het lag voor de hand, deze in het groot uit het vaderland mee te nemen. Door vroegere reizen in de Tropen wisten mijn vrouw en ik ongeveer, wàt we mee wilden nemen, maar natuurlijk moesten de jongelui onze keuze goedkeuren. Welk een tegenstelling tusschen de verheugde gezichten der zes, toen ze op een zeer kouden winteravond allerlei blikjes even kostelijk en heerlijk vonden en de lange gezichten, waarmede ze later, na eenige maanden verblijf in de Tropen, tegen corned beef, gehakt uit blik, vischjes „,van diverse pluimage”, roggebrood en halfgesmolten boter zaten aan te kijken!

Wat de wetenschappelijke voorbereiding der reis betrof heeft de bioloog, die geheel onafhankelijk van de anderen was, er zelf voor gezorgd, zich voor te bereiden, terwijl de geologen met mij natuurlijk kennis namen van de literatuur over de eilanden en de omringende gebieden en zich een idee vormden van de vraagstukken, die er aan de orde waren.

\section{III.}

Den 21 Maart 1930 vertrokken we per S.S. Crijnssen naar Curaçao, vol hoop en vertrouwen op een schoone en vruchtbare reis. Ons algemeen plan was als volgt. We wilden eerst drie weken op Curaça,o werken. Wel was kortgeleden Molengraaff's monographie over dit eiland verschenen, maar verschillende deelen had hij, naar hij ons zelf had verteld, niet voldoende nauwkeurig kunnen bewer- 
ken. Dit gold in de eerste plaats voor de omgeving van Porto Marie en Casabau, in de tweede plaats voor gebieden om St. Kruis, ten laatste, tot op zekere hoogte, ook voor de omgeving van Savonet. Als we drie weken kampeerden in Porto Marie, St. Kruis en Savonet, gaf ons dat de gelegenheid, ons op het klimaat in te stellen, de geologische formaties van Curaçao - die zeker allerlei vergelijkbaars hadden met die op Aruba en Bonaire - grondig te leeren kennen, terwijl we bovendien de kans hadden, de geologische kaart van het eiland te verfraaien en onze kennis van de geologie van Curaçao te vermeerderen.

Daarna hadden we het plan, Aruba en Bonaire grondig te onderzoeken. We vermoedden, dat we daarna nog wel wat tijd zouden overhouden en hoopten dien te gebruiken voor het onderzoek van een aantal, bijna geheel onbekende Venezolaansche eilandjes tusschen Trinidad en Bonaire. Door de welwillende bemiddeling van het Departement van Buitenlandsche Zaken en den Nederlandschen Gezant te Caracas, den heer W. d'Artillact Brill hadden we voor dit onderzoek reeds de toestemming der Venezolaansche Regeering verkregen. Een van de weinige teleurstellingen op onze reis is geweest, dat we van deze toestemming geen gebruik hebben kunnen maken.

Hoe heerlijk is het, om, als men zelf de Tropen kent, met zes jongelieden, die vol belangstelling voor de natuur zijn, een zeereis naar de warme streken te maken! Men geniet nog eenmaal als toen men zijn eerste zeereis maakte, en men geniet zesvoudig! De kusten van Boulogne en Dover, de scharen van meeuwen, die dagenlang het schip volgen, de eenzame zeevogels, die men tot ver in den oceaan ziet, het varen door de met wieren bedekte deelen van den atlantischen oceaan tusschen de Azoren en Barbados, waar uren lang gevischt werd, om wier en dieren op te halen, de eerste vliegende visschen en bruinvisschen, het opkomen van den passaat: het waren alles ervaringen, om verrukt over te worden. Veel grooter was echter de extase der jongelui, toen we in Barbados het eerste tropische land bezochten. Voor het eerst koraalriffen te zien, voor het eerst een land met echt tropische planten te 


\section{GEOLOGISCHE REIS MET UTRECHTSCHE STUDENTEN}

zien, die men misschien uit een hortus kent, maar die nú opeens veel meer realiteit krijgen, door een stad met een lawaaiige tropische bevolking te loopen en de ervaring op te doen, dat men negers als bevolking niet alleen ziet, maar ook ruikt: dat alles ontlokte aan de studenten een zóó ononderbroken stroom van uitroepen van verrukking dat men als leider al door het zien van zooveel genieten schadeloos zou gesteld zijn voor veel latere ergernis en vermoeienissen. Laat ik dadelijk zeggen, dat ergernissen en overmatige vermoeienissen later uitgebleven zijn.

$\mathrm{Na}$ de genotvolle uren op Barbados komt er dan nog zooveel anders. Het varen door de schoone „bocas” bij Trinidad, waar men de eerste pelikanen ziet; na het groene Trinidad het varen langs het woestijnachtige Margarita; de onvergetelijke zonsopgang op de reede van La Guaira; de tocht van La Guaira naar Caracas. Zoozeer was de jeugd toen al verzadigd met nieuwe indrukken, dat er één verklaarde, dat, als hij nu moest teruggaan, hij al tevreden over zijn reis zou zijn.

Maar tegelijk met het genieten van zooveel nieuws treedt een zekere matheid op; men begint te verlangen, om eindelijk het doel te bereiken en aan het werk te kunnen gaan. Vandaar ook, dat iedereen tevreden was, toen we op een - natuurlijk zonnigen - morgen de St. Annabaai van Curaçao binnenvoeren, dat zich al dadelijk sympathieker voordeed dan zijn reputatie is. Immers: de oostoever van de St. Annabaai is vrij dicht begroeid met lage, op dien dag er frisch-groen uitziende boomen, en het was heelemaal niet waar, wat de zeeman van het eiland zegt :

"Geen boom ontsiert de kale klip."

IV.

Wie wel eens een reis naar een overzeesch land heeft gemaakt en daar niet door vrienden ontvangen werd, weet, hoe onaangenaam debarqueeren kan zijn. De schreeuwerige koelies, de eigenaren van bootjes, die $\mathrm{U}$ aan wal willen brengen, de portiers, die hotels aanprijzen, het gevoel, 
NAAR DE NEDERL. BENEDENWINDSCHE EILANDEN 297

dat men onderweg naar het hotel zeker wat van zijn talrijke bagage verliest, en eindelijk het aankomen in een, vaak primitieve, voor alle bagage te kleine hotelkamer, waar men zich dan ergert over de wijze, waarop men door alle lieden, die bij het debarqueeren geholpen hebben, afgezet is: het zijn alles ervaringen, die het einde eener zeereis hoogst onverkwikkelijk kunnen maken. Hoe anders was onze aankomst te Curaçao, waar we bij „Curaçaosche Petroleum Industrie Maatschappij" als in Abraham's schoot binnenvielen. Nauwelijks lag de boot stil, of de ontschepingsambtenaar der CPIM, de heer Slokkers, kwam met zijn volle welwillendheid aan boord, en hielp ons door alle douane- en pasformaliteiten heen; een oogenblik later kwam een der chemici der CPIM, Jhr. Dr. Van den Bergh, die ons aldoor een goed raadgever is gebleven, en kort daarna kwam de directeur zelf, Ir. C. van der Stok, ons afhalen. De zes studenten werden ondergebracht in een der jonggezellenhuizen van de maatschappij, en mijne vrouw en ik waren te gast in het directiepavilloen, terwijl voor onze, zeer talrijke bagage een leege autogarage beschikbaar werd gesteld. Zoo voelden we ons na eenige uren in Curaçao al volkomen thuis. Ook van andere zijde werd ons de grootste welwillendheid betoond: de administrateur van Financiën, de heer H. Schotborgh, kwam me nog dienzelfden middag opzoeken - ik was zelf door een val niet in staat, hem het eerste bezoek te brengen - en gaf ons raad over de plantages, waar we wilden kampeeren, en nam op zich, eenige negerbedienden voor ons te laten aanwerven.

Ik had gehoopt, twee mannelijke negerbedienden voor ons gezelschap te kunnen krijgen, gelijk men ook in OostIndië buiten altijd met mannelijk personeel reist. Dit was echter onmogelijk, en, tot verbazing van de jongelui stonden eenige dagen later in Porto Marie twee brave negerinnen,luisterend naar de namen Harrietta en Catharina op ons te wachten. Zij zijn ons op alle eilanden trouw gebleven. Men kan zich voorstellen, hoe blij ik was, dat mijne vrouw ons vergezelde: wat voor een indruk zou het gemaakt hebben, als in het vaderland het bericht doorge- 


\section{GEOLOGISCHE REIS MET UTRECHTSCHE STUDENTEN}

drongen was, dat ik met zes studenten en twee negerinnen de binnenlanden der Benedenwindsche eilanden was ingetrokken!

Onze driewekelijksche kampeertocht op Curaçao is slechts mogelijk geweest, doordat de CPIM ons bij voortduring daadwerkelijk geholpen heeft. Wanneer er een nieuw kamp moest betrokken worden, leende zij ons auto's en auto-vrachtwagens voor vervoer van ons zelf en van onze bagage. Van veel meer belang was echter, dat zij ons met drink- en waschwater heeft geholpen. Het is bekend, hoe ongunstig in den laatsten tijd de „watertoestand” op de eilanden is, het gevolg van zeer arme regentijden in verschillende opeenvolgende jaren. Op onze eerste kampeerplaats, Porto Marie, kon de eigenaar, de heer Royer, nog een put ter onzer beschikking stellen, waar we rijkelijk waschwater vonden; op de volgende plantages, St. Kruis en Savonet, was echter de waterschaarschte zoo groot, dat het teveel van de vriendelijkheid der eigenaren, de heeren De Jong en Van der Linde Schotborgh gevergd zou zijn geweest, hunne regenbakken of putten méde te gebruiken. Hier heeft ons nu de CPIM geholpen, door niet alleen groote hoeveelheden gechloreerd drinkwater, maar ook drums met waschwater ter onzer beschikking te stellen.

Curaçao heeft den naam, een leelijk, dor eiland te zijn, waar altijd een hinderlijke passaat waait. Onze indruk is in menig opzicht geheel anders geweest. Zeker: het eiland is dor en droog, maar hoe belangwekkend en fraai is voor den natuuronderzoeker de, aan dit klimaat aangepaste flora. Hoe mooi zijn in hun soort de cactussen in hun groote verscheidenheid, de verschillende agaves, de doornige mimosabosschen en de, door den wind verwaaide divi divi boomen. Hoe prachtig kunnen bouquetten van felgeel bloeiende quiebrachaboomen tegen het overigens dorre bosch afsteken. Hoe mooi zijn de eindelooze wolkenkudden, die over het eiland trekken, hoe mooi de kleuren van het kale land in avond- en morgenzon, hoe fraai ten laatste de bergvormen in het Noordwesten, culmineerend in den phantastischen Christoffelberg. Hoe prachtig zijn 
de kusten met hunne witte, lichtelijk begroeide terrassen van opgeheven koraalkalk, waartegen in het Westen de meest rustige zee met hare koralen en zeeappels aanligt, terwijl in het Oosten de eeuwige muziek is van aangaloppeerende en verstuivende passaatgolven. De hinderlijke passaat? We hebben hem gezegend, als hij ons overdag het wandelen en klimmen in de felle zon, met een rugzak vol steenen, mogelijk maakte, doordat hij ons aldoor iets afkoelde, als hij ons des avonds koelte op onze kampeerplaatsen bracht, en we hebben hem alleen verwenscht, als hij onze primuskomforen uitblies en ons dwong, heele bouwsels van tenten en leege kisten te maken, in wier windschaduw de komforen ongestoord konden branden.

Herhaaldelijk gebeurt het, dat leeken vragen, wat eigenlijk een geoloog bij het onderzoek van een land doet. Of hij boorgereedschappen meeneemt, om den ondergrond te onderzoeken, of hoe hij op andere wijze iets over den ondergrond kan te weten komen. Bij ons werk op de eilanden - zooals trouwens bij het meeste geologische werk maakten we nimmer van eenig boorgereedschap gebruik. De eenige keer, dat we tot op eenige diepte in den ondergrond drongen, was in Bonaire, waar we eenige putten in aanbouw bezochten en waar we op één plaats een sleuf van eenige decimeters(!) diepte maakten. Als regel, en zoolang het niet om zeer speciale vraagstukken gaat, heeft de geoloog het echter niet noodig, ontgravingen of boringen te maken. Op vele plaatsen toch komt het gesteente van den ondergrond min of meer onverweerd aan de oppervlakte, en, door te combineeren, wat hij op zooveel mogelijk plaatsen aan de oppervlakte ziet, kan zich de geoloog een beeld vormen van den toestand in den ondergrond van een land. Ons werk verliep dus als volgt. Voorzien van topographische kaarten, geologische hamers, kompassen en nog eenige ingrediënten gingen we elken dag, meest in ploegen van twee, van ons kamp in verschillende richtingen, bekeken alle plekken, waar de gesteenten van den ondergrond behoorlijk zichtbaar zijn aan de oppervlakte, noteerden het waargenomene en namen zoo noodig monsters van de gesteenten of van de erin voorko- 


\section{GEOLOGISCHE REIS MET UTRECHTSCHE STUDENTEN}

mende versteeningen mede, om deze later in het laboratorium te kunnen onderzoeken. Het gaat er dus om, een zoo dicht mogelijk net van waarnemingen te maken, om later hieruit de geologische kaart te vervaardigen, en uit deze en de meegenomen monsters de geologische geschiedenis van het gebied te reconstrueeren. Een dergelijke geologisch onderzoek valt dus altijd uit elkaar in twee gedeelten: het „veld” onderzoek, waarbij het waarnemingsnet over het te onderzoeken gebied gelegd en de noodige gesteentemonsters verzameld worden, en het, soms veel langer durende laboratoriumwerk, waarbij de medegenomen gesteentemonsters onderzocht worden en de geologische kaart uitgewerkt wordt. Een paar voorbeelden, ontleend aan Curaçao kunnen dit toelichten ${ }^{\mathbf{1}}$ ). Curaçao is niet altijd een, door diepe zee omgeven, klein eiland geweest. Er is een tijd geweest, in het allerjongste deel der Krijtperiode of in het alleroudste deel der Tertiaire periode, toen, waar nu Curaçao ligt, zich een ondiepe zee bevond, waarin allerlei puin gespoeld werd van een, in de nabijheid liggend landgebied. Iets later werden de lagen, die zich op den bodem dezer zee hadden afgezet, en die men tegenwoordig aanduidt als de „Midden Curaçao lagen” (omdat men ze in Midden Curaçao het beste bestudeeren kan) geplooid en opgeheven. In dien tijd vormde Curaçao een onderdeel van een veel grooter eiland of landgebied. Een aantalveldonderzoekingen met aansluitend laboratoriumwerk hebben betrekking gehad op dit deel der geologische geschiedenis van het eiland: Aan den Seroe Teintje bij Savonet vindt men fossielen in een kalksteen, die ouder is dan de „Midden Curaçao lagen”. Uit dezen kalksteen zijn reeds door Martin fossielen verzameld; ons gezelschap kon er nog een aantal zeer fraaie versteeningen bijeenbrengen, die kenmerkend zijn voor het Boven-Krijt. De „Seroe Teintje kalksteen” is ouder dan de „Midden Curaçao lagen”, omdat in deze laatste afgerolde stukken van de ,Seroe Teintje kalk” voorkomen: de „Midden Curaçao laggen” zijn dus op zijn oudst Bovenste Krijt. Uit resten van

1) In een volgend nummer van dit tijdschrift denk ik, de geologische geschiedenis der eilanden uitvoeriger te behandelen. 
planten en dieren, die in de „Midden Curaçao lagen” voorkomen, kan men concludeeren, dat ze in een ondiepe zee zijn afgezet: er werden n.l. oesters en kalkwieren verzameld, kenmerkend voor de kustzone. Als kleine afgerolde steentjes komen in de „Midden Curaçao lagen” gesteenten voor, die onmogelijk van het tegenwoordige eiland afkomstig kunnen zijn: in de ondiepe zee kwam dus afgespoeld materiaal van een, in de buurt liggendland terecht. De plooien der „Midden Curaçao lagen”, wier aanwezigheid men tijdens het veldonderzoek constateert, waren oorspronkelijk zeker niet tot het eiland beperkt, want ze loopen op sommige plaatsen recht de zee in, en vertellen ons, dat na hun ontstaan Curaçao deel heeft uitgemaakt van een grooter landcomplex. Van de bovengenoemde feiten werden een deel tijdens het veldonderzoek verkregen (waarnemingen over plooiïngsrichting der „Midden Curaçao lagen”, verzamelen van fossielen uit "Seroe Teintje kalk” en "Midden Curaçao lagen”, verzamelen van gesteentemonsters), een ander deel kon eerst bij het aansluitende laboratoriumwerk blijken (aard der fossielen, aard der, als rolsteen in de ,,,Midden Curaçao lagen” voorkomende gesteenten ${ }^{\mathbf{1}}$ ).

\section{V}

Toen we na drie weken kampeeren weer naar Emmastad, de zetel van de CPIM terugkwamen, konden we geacht worden, geheel in het onderzoek der eilanden ingewerkt te zijn.

De Gouverneur van Curaçao, de heer B. Van Slobbe, was zoo vriendelijk, ons toe te staan, met een der, bij de eilanden gestationeerde torpedojagers naar Bonaire te varen, en op de hoofdplaats van het eiland, Kralendijk, in het gouvernementslogeerhuis onzen intrek te nemen. $\mathrm{Na}$ enkele dagen vertrokken we dan ook per H.M. Witte de With naar Bonaire; op den, helaas slechts enkele uren du-

1) Ik moet erop wijzen, dat een deel der, in de gegeven voorbeelden genoemde waarnemingen bereids door Molengraaff gedaan waren. De voorbeelden zijn niet speciaal gegeven, om aan te toonen, wat wij deden. 


\section{GEOLOGISCHE REIS MET UTRECHTSCHE STUDENTEN}

renden overtocht voortdurend aangenaam bezig gehouden door den commandant, den heer E. Vreede en de andere leden van den staf. Op Bonaire werden we allervriendelijkst ontvangen door den Gezaghebber, den heer H. B. C. Schotborgh en door Mevrouw Schotborgh; tijdens ons verblijf hebben we bij voortduring van hun gastvrijheid, van hun hulp en van hun raad genoten en geprofiteerd. Ook de heer Herrera, de voornaamste plantagebezitter van het eiland en de medicus, de heer Polak, hebben ons met roerende vriendelijkheid geholpen en met raad ter zijde gestaan.

Oorspronkelijk zullen Bonaire en Curaçao ongeveer gelijke eilanden geweest zijn: klimaat en ondergrond is sterk verwant, en flora en fauna zullen oorspronkelijk zeker ongeveer gelijk geweest zijn. Hoe sterk is echter nú in vele opzichten de tegenstelling. Curaçao staat in vele opzichten in het teeken der industrie: het geweldige petroleumbedrijf en de drukke haven drukken hun stempel op alles. Door intensievere en langere bewoning zijn de bosschen op Curaçao voor een belangrijk deel al uitgeroeid; de plantages beteekenen niet veel meer voor de economie van het eiland; de werkkrachten zijn sterk geconcentreerd in de omgeving van Willemstad; de toestanden op het eiland hebben weinig patriarchaals meer. Hoe anders is de toestand op Bonaire. Wel is ook hier een belangrijk deel der mannelijke bevolking weggetrokken, hetzij om te werken in raffinaderijen der CPIM, hetzij om als matroos de Caribische zeeën te bevaren, maar dat neemt niet weg, dat de toestanden op het eiland nog iets idyllisch-patriarchaals hebben. De bevolking is lang zoo dicht niet als in Curaçao; er is geen enkele groote industrie; een groot deel der, op het eiland verblijvende bevolking leeft van landbouw- en boschbedrijf; van landbouw inzooverre, als ze werkt op de groote aloëplantages, wier opbrengst juist in den tijd van ons bezoek door sterk gestegen aloë-prijzen weer loonend was geworden, van boschbedrijf inzooverre, als ze houtskool brandt in de, nog vrij uitgestrekte boschcomplexen van het noordelijk deel van het eiland. Curaçao is zeker op het oogenblik een rijker eiland dan Bonaire; in menig opzicht gaf echter Bonaire blijken van een gezon- 
NAAR DE NEDERL. BENEDENWINDSCHE EILANDEN 303

dere welvaart. Op Curaçao uit zich de weelde der gekleurde bevolking vooral in mooie zijden kleeren, waarin de negers op Paaschzondag naar de mis gaan en in een enorm groot aantal leege jeneverflesschen, die men op vele plaatsen in den omtrek der huizen en langs de wegen ziet liggen; de huizen daarentegen zijn veelal zeer armoedig en primitief. Op Bonaire - en dit geldt zoowel van de hoofdplaats Kralendijk als van het dorpje Rincon in Noord Bonaire - trof ons het groote aantal van nieuwe steenen huizen, voor een deel van goede regenbakken voorzien: een aanwijzing, dat de bevolking het op Curaçao of op de zeilschepen in de Caribische zee verdiende geld op degelijke wijze belegde.

Bonaire was een, geologisch nog zeer weinig bekend eiland: we hebben ongeveer vijf weken noodig gehad voor het onderzoek. Gedurende een deel van dien tijd konden we wonen in het groote en prachtig aan de zee gelegen gouvernementslogeerhuis in Kralendijk; bijna een week konden we verblijven in een, aan den heer Herrera behoorend landhuisje in Fontein, waar de eenige natuurlijke bron van het eiland is, wier water in groote gemetselde bakken stroomt, die een ideale zwem- en bad-gelegenheid verschaffen; den langsten tijd hebben we gekampeerd bij een put in Noord Bonaire, „Dos Poos” genaamd, waar een groot deel der bevolking van het dorp Rincon haar drinkwater komt halen. Dit was een ideaal kampement: onze tenten stonden onder groote tamarindeboomen in de buurt van de put, waar den heelen dag een vroolijke bevolking met ezeltjes, die vaten droegen, water kwam scheppen en kwam wasschen. Meer dan op eenig ander terrein zijn we hier met de bevolking in aanraking gekomen, en deze aanraking heeft zelfs nog geologisch resultaat gehad, inzooverre, als een alleraardigst herdersjongetje, Aloysius geheeten, ons een vindplaats van zeer belangwekkende, tertiaire fossielen heeft gewezen. Elk eiland heeft zijn bijzondere charme gehad, maar ik geloof toch, dat als men mijn reisgenooten vraagt, wat zich het meest in hun geheugen heeft gegrift, zij zullen zeggen, dat het het kamp bij Dos Poos was, waar we vriendschappelijk omgingen met ne- 
gers, schapen, geiten en varkens, en waar in de buurt het prachtige zoutwatermeer Goto lag met de groote kolonie van prachtige flamingo's.

Het is hier niet de plaats, om veel te zeggen over de geologie van Bonaire. De geologische geschiedenis vertoont menig punt van overeenkomst, maar ook belangrijke verschillen met die van Curaçao. Evenals op Curaçao wordt het fundament van het eiland gevormd door vulkanische gesteenten, die in de Krijtperiode zijn ontstaan, en die veel gelijkenis hebben met verwante gesteenten in het meest oostelijke deel van Curaçao. Evenals Curaçao eenmaal deel heeft uitgemaakt van een grootere landmassa, is dit ook met Bonaire het geval, en ook op Bonaire treffen we afzettingen aan van rolsteenen, die van elders moeten zijn aangevoerd. Treffend is de gecompliceerdheid der jongere geschiedenis van Bonaire: minstens viermaal is het eiland, nadat het vulkanische fundament was gevormd, in zee ondergedompeld en weer opgerezen!

De resultaten van ons onderzoek op Curaçao zijn voor de economie van het eiland zonder eenig belang geweest. Eenigszins anders is het op Bonaire. Wanneer eenmaal de geologische kaart van het eiland zal zijn gepubliceerd, zal deze als leiddraad kunnen dienen bij het aanzetten van nieuwe waterputten en van stuwdammetjes. Daarmede is niet gezegd, dat men zeer veel meer water zal kunnen vinden dan nu het geval is, maar eenerzijds zullen toch enkele punten kunnen aangegeven worden, geschikt voor het maken van proefputten en van stuwdammen, terwijl anderzijds het maken van volmaakt ongemotiveerde putten - waarvan er o.a. twee tijdens ons bezoek in bewerking waren — zal kunnen worden uitgeschakeld.

\section{VI.}

Per H.M. Witte de With werden we naar Bonaire gebracht; een zusterschip, H.M. Van Galen, onder commando van den luitenant ter zee 1ste klasse $H$. Nieuwenhuys haalde ons weer af en bracht ons terug naar Curaçao. De terugreis was bijna nog prettiger dan de heenreis: we voel- 
den ons nu al zoo thuis op Harer Majesteit's schepen! In Curaçao ondervonden we tijdens een oponthoud van een viertal dagen weer vriendelijkheden en hulp van alle instanties bij Gouvernement en CPIM; dank zij deze hulp konden we reeds na zóó korten tijd weer naar Aruba vertrekken. Het kleinere en eenvoudigere Aruba heeft ons drie weken aan het werk gehouden; dank zij het groote aantal, op het eiland rijdende autobussen, auto's en autovrachtwagens, die ons vaak een „lift” gaven, konden we het onderzoek van twee centra uit doen: van Oranjestad, waar we wederom in het Gouvernementslogeerhuis mochten wonen en van Fontein aan de Oostkust, waar we een bijzonder fraai kamp in een grot, op nog geen kilometer van zee verwijderd, hebben gehad. Ook op Aruba zijn we prettig geholpen: in de eerste plaats door den Gezaghebber, den Heer L. Wagemaker, die al voor onze komst zijne vaderlijke zorgen begonnen was, inzooverre, als hij in de kerken van den preekstoel had laten aankondigen, dat we zouden komen, waarbij de bevolking gevraagd was, ons te helpen en op alle landerijtjes toe te laten, en die ons ook tijdens ons verblijf aldoor welwillend geholpen heeft; vervolgens door den commandant der mariniers, 1ste Luitenant C. Janssens, ten laatste door den eigenaar der plantage Fontein, die ons toestond, in zijne bron te baden; een gunst, die alleen zij naar waarde kunnen schatten, die in landen, waar zoetwaterschaarschte heerscht, vertoefd hebben.

Niet alleen in geologisch opzicht was voor ons het bezoek aan Aruba loonend. Na Bonaire, dat geheel landbouw- en veeteelt-eiland is, na Curaçao, waar weliswaar bij de hoofdplaats een geweldige industrie is, maar waar men toch in de „koenoekoe” nog groote kudden van geiten, ezels, ja zelfs van paarden en koeien vindt, en waar op zoo menige plaats een groenend hofje te vinden is, waar gedurende het heele jaar vruchten en andere landbouwproducten gekweekt kunnen worden, kwam Aruba als de meest felle woestenij, waar men veel minder vee ziet dan op de andere eilanden, waar maar zeer enkele groene, geïrrigeerde „hofjes” gevonden worden, waar de 
velden, na de lange periode van droogte, volmaakt verdord waren, zóó, dat het moeite kostte te begrijpen, dat men deze dorre steen- en zandvlakten nog zoo zorgvuldig omheind had. Wel lagen er nog groote aloë-tuinen, maar ze werden niet meer bewerkt, omdat, in weerwil van de hooge aloëprijzen de winning niet kon geschieden als gevolg van de hooge loonen. Met die groote dorheid gaat echter op Aruba gepaard een schoonheid van landschapskleuren, die alles op de andere eilanden overtreft. Speciaal in het Noorden van het eiland ziet men in de morgenuren en late middaguren de prachtigste tinten van bruin en rood, waartegen de witte stranden en de blauwe zee zeer schoon afsteken. Zeer merkwaardig was tijdens ons verblijf de economische toestand op Aruba, inzooverre als hij in het geheel niet overeenkwam met de erbarmelijke armoedigheid van zijn bodem. Sedert kort was de groote petroleumraffinaderij bij St. Nikolaas in bedrijf gekomen, en hierdoor was niet alleen een golf van welvaart over de arbeidende bevolking gekomen, maar er waren bovendien als indirect gevolg allerlei andere groote werken in aanleg. Men was bezig een groote autoweg van de hoofdplaats naar St. Nikolaas te bouwen; er werd een aanlegsteiger in Oranjestad gemaakt; allerlei andere werken waren in uitzicht. Daar kwam nog bij, dat er op groote schaal kwartszand ontgonnen en naar Curaçao verscheept werd: kortom, er heerschte een bedrijvigheid, die zoo in tegenspraak leek met den natuurlijken toestand van het eiland, dat de indruk, dien men kreeg, iets onwezenlijks had.

Van de geologie van Aruba was veel meer bekend dan van die van Bonaire, wat niet wegneemt, dat we over de resultaten van ons onderzoek zeer tevreden zijn geweest. Men kan zeer in het algemeen zeggen, dat de drie Benedenwindsche eilanden geologisch verwant zijn; gelijke formaties hebben ze opgebouwd. Maar Aruba is, geologisch gesproken, het hoogste opgeheven, Curaçao is minder hoog opgeheven, Bonaire het minste. Aangezien nu de tegenwoordige hoogte der eilanden niet zoo heel veel verschilt (Aruba rijst tot $188 \mathrm{~m}$., Curaçao tot $372 \mathrm{~m}$., Bonaire tot $240 \mathrm{~m}$. omhoog), is het gevolg, dat men op Aruba het 
diepste deel van het fundament der eilanden bestudeeren kan, terwijl de gesteenten, die men op Bonaire vindt, steeds de meest oppervlakkige geweest zijn. Aangezien nu een groot deel der geologische gebeurtenissen aan de oppervlakte plaats vindt, kennen we de geschiedenis van Bonaire vollediger dan die van Aruba, maar pas door het beschouwen van de geologie der drie eilanden krijgt men een goed overzicht van de geheele geologische geschiedenis van het gebied. Inzooverre waren de drie eilanden samen een zoo fraai object voor een onderzoekingsreis.

Evenals voor Bonaire zal men in Aruba, wanneer de geologische kaart van het eiland verschenen is, deze kunnen gebruiken voor het meer rationeel aanzetten van waterputten en stuwdammen.

Ons tweede kamp in Aruba, in de kalksteengrot van Fontein, was bijna even idyllisch als het kamp bij Dos Poos in Bonaire. Boven ons hoofd stonden op het dak der grot allerlei onbegrepen teekens, in vroeger eeuwen door de oorspronkelijke Indianenbevolking aangebracht; daarnaast zag men de namen van tallooze blanken, die in de laatste 100 jaar de grot bezocht hebben; naar buiten kijkende, had men een prachtig uitzicht op het laagste koraalkalkterras en op de zee. Maar, in tegenstelling met Dos Poos, was dit kamp geheel dood. Geen bevolking kwam in de buurt; gedurende den heelen tijd van ons verblijf is het kamp hoogstens door tien menschen bezocht. Toch hebben we de beste herinneringen aan dit laatste kamp op de eilanden. We waren het beste ingeloopen, en daardoor minder vermoeid dan in vroegere kampen. Behalve met de geologie hielden de verschillende leden van ons gezelschap zich met verschillende werkzaamheden van zoologischen en botanischen aard bezig. Er werden vogels verzameld voor het Museum van Natuurlijke Historie te Leiden. insecten voor het museum van „Artis” in Amsterdam, terwijl onze bioloog alle dierlijke wezens, die hij kon bemachtigen, inpalmde. Ik heb den indruk, dat we in geen enkel kamp zooveel van de fauna gezien hebben als juist in ons grot-kamp van Fontein. Hoe prettig was het, om, als men des avonds met zijn geologisch werk ge- 
reed was, dezen bezig zag met het prepareeren van krabben en het conserveeren van allerlei zeedieren, genen met het sorteeren van de, in den loop van den dag gevangen insecten, weer andere met het prepareeren van vogels!

VII.

Op Aruba ontvingen we een uitnoodiging, die al onze latere plannen veranderde. Op initiatief van den chefgeoloog Dr. Ritter der "Caribbean Petroleum Company”, de dochtermaatschappij der „Koninklijke” in Venezuela, ontvingen we de uitnoodiging, om enkele weken naar Venezuela te komen, de gasten der Maatschappij te zijn en, onder leiding van hare geologen, enkele groote excursies door Noordwestelijk Venezuela te maken. Is het noodig te zeggen, dat we dit aanbod met beide handen aangrepen? Wel eindigde hierdoor het exploratieve deel van onze reis, maar we kregen gelegenheid, om onder de beste leiding een indruk te krijgen eenerzijds van de geweldige petroleumindustrie van Venezuela, anderzijds van de geologie van een belangrijk deel van dit land, wat weer van veel belang voor ons was voor beter begrip van wat we op de eilanden hadden gezien. Maar bovendien zagen we op deze reis zooveel andere dingen. De klimatische variaties in Venezuela zijn zoo snel, dat we op onze excursies herhaaldelijk den overgang van vochtig tropisch oerbosch door park- en savanna-land naar halfwoestijn hebben meegemaakt, en voor de jongelieden was het een ervaring voor hun leven, om kennis te kunnen maken met toestanden, opvattingen en menschen in een der Latijnsch-Amerikaansche republieken.

$\mathrm{Na}$ ons bezoek aan Venezuela was onze West-Indische reis afgeloopen: Op Curaçao hadden we maar enkele uren den tijd, om van den „Libertador” op de „Venezuela”, die ons naar Amsterdam zou brengen, over te gaan, en om dankbaar afscheid te nemen van allen, die geholpen hadden, onze reis zoo uitnemend te doen slagen.

Ik ben er zeker van, dat alle jongere deelnemers veel van hunne reis geleerd hebben. Maar misschien is even 
NAAR DE NEDERL. BENEDENWINDSCHE EILANDEN 309

belangrijk als de vak-ervaringen, die ze hebben opgedaan de leerschool, die ze in solidariteit en in "aanpakken” hebben gehad. Persoonlijk zal ik tenminste niet de grootste voldoening hebben op den dag, dat de heeren Westermann en Pijpers op hunne dissertaties over Aruba en Bonaire promoveeren, maar heb ik reeds de grootst mogelijke voldoening gesmaakt op den dag, toen we in Amsterdam aankwamen, toen iedereen door familie en kennissen werd afgehaald, en toen één der afhalenden van achter het douanehek riep: „Wat hebt U met ...... gedaan; hij draagt koffers en sjouwt met kisten, dàt heb ik nog nooit gezien."

Utrecht. 